Faculty of Science

Faculty Publications

Three new species of Cladorhiza (Demospongiae, Poecilosclerida, Cladorhizidae) from the Northeast Pacific Ocean

Lonny Lundsten, Henry M. Reiswig, and William C. Austin

2017

(c) 2017 Magnolia Press. This is an open access article distributed under the terms of the Creative Commons Attribution License. http://creativecommons.org/licenses/by/3.0

This article was originally published at:

http://dx.doi.org/10.11646/zootaxa.4317.2.3

Citation for this paper:

Lundsten, L.; Reiswig, H. M.; \& Austin, W. C. (2017). Three new species of Cladorhiza (Demospongiae, Poecilosclerida, Cladorhizidae) from the Northeast Pacific Ocean. Zootaxa, 4317(2), 247-260. DOI: 10.11646/zootaxa.4317.2.3 


\title{
Three new species of Cladorhiza (Demospongiae, Poecilosclerida, Cladorhizidae) from the Northeast Pacific Ocean
}

\author{
LONNY LUNDSTEN ${ }^{1,5}$, HENRY M. REISWIG ${ }^{2,3} \&$ WILLIAM C. AUSTIN ${ }^{4}$ \\ ${ }^{1}$ Monterey Bay Aquarium Research Institute, 7700 Sandholdt Drive, Moss Landing, California 95039, USA \\ ${ }^{2}$ Department of Biology, University of Victoria, Victoria, British Columbia V8P 5C2, Canada \\ ${ }^{3}$ Natural History Section, Royal British Columbia Museum, Victoria, British Columbia V8W 9W2, Canada \\ ${ }^{4}$ Khoyatan Marine Laboratory, North Saanich, British Columbia V8L 5G5, Canada \\ ${ }^{5}$ Corresponding author
}

\begin{abstract}
Carnivorous feeding among the Cladorhizidae (Porifera, Demospongiae, Poecilosclerida) was first documented in 1995. Since that time, 161 species have been described and are currently recognized in 9 genera. Cladorhiza is the most speciose genus with a global, deep-water distribution of 41 species. Here we describe three new Cladorhiza species of 'crinorhiza' form from the Northeast Pacific Ocean off California, USA, and the Gulf of California, Mexico, from depths of 2472$4100 \mathrm{~m}$. In total, 11 specimens were collected between 1969 and 2015. Video recordings from remotely operated vehicles yield additional information on habitat type, geographic distribution, and abundance for some of these species.
\end{abstract}

Key words: Porifera, Cladorhizidae, Cladorhiza, deep-sea

\section{Introduction}

In the Cladorhizidae, macrophagy provides metabolic advantages to microphagous filter feeding and, excitingly, demonstrates a morphology and biological function that is strikingly different from what is described for the phylum (Vacelet \& Boury-Esnault 1995). In his description of Cladorhiza abyssicola, Sars (1872) described the peculiar lack of oscula, pores, and flagellated chambers and suggested, however unlikely, that the species may have some other means of obtaining nutrients, i.e., differing from the filter feeding described for the phylum Porifera. Vacelet \& Boury-Esnault (1995) discovered a deep-water species of Cladorhizidae living in a shallow, SCUBA accessible, cave in the Mediterranean where specimens could be easily collected and observed, verifying, for the first time, carnivory in sponges and validating Sars' original observation from 123 years earlier. Carnivory in these sponges is thought to be an adaptation to living in the deep sea, and other nutrient-deprived environments, where filter feeding and requisite maintenance of an aquiferous system, found in most sponges, would be metabolically costly (Vacelet \& Boury-Esnault 1995, Leys et al. 2011). Other abundant deep-sea sponge species, such as members of the Hexactinellida, may have evolved to utilize ambient current flow to mitigate the metabolic costs of filtering (Leys et al. 2011). Modern cladorhizids have, except in species of Chondrocladia, entirely lost the aquiferous system.

Carnivorous sponges are a monophyletic group of sponges with a lineage dating to the early Jurassic. There are currently 161 species of Cladorhizidae recognized from 9 genera (Van Soest et al. 2017). Using molecular techniques and morphological characters, Hestetun et al. revised the phylogeny of the Cladorhizidae, reassigning several carnivorous taxa from other families in the Poecilosclerida to genera within the Cladorhizidae, demonstrating 1) that carnivory has evolved in one familial lineage within the Poecilosclerida and 2) monophyly for the family Cladorhizidae (Hestetun et al. 2016). Trochirhabd spicules from two recently described species of Chondrocladia closely match fossil spicules described from early Jurassic sedimentary deposits, suggesting that the Cladorhizidae may have been present 200-250 mya (Vacelet and Kelly 2008). 
Prey capture and consumption (Vacelet \& Duport 2004; Chu \& Reiswig 2014) has been described for some cladorhizids and, in general, it is thought that crustacean prey are passively ensnared by mechanical entrapment of crustacean limbs within the gauntlet of hook-like chelae covering prey capture locations, which varies based on species. For example, in Cladorhiza pteron prey capture appears to be limited to marginal filaments (Vacelet \& Duport 2004, Reiswig \& Lee 2007, Lee et al. 2012), whereas species of Chondrocladia may use inflated spheres for prey capture (Kubler \& Barthel 1999) or stolons, branches, and terminal balls as seen in Chondrocladia lyra (Lee et al. 2012). Cladorhiza methanophila is a species that inhabits mud volcanoes in the Barbados Trench and it appears to derive a portion of its nutrients from the intracellular digestion of chemosynthetic symbionts (Vacelet et al. 1996). Lundsten et al. (2014) described Asbestopluma rickettsi from a chemosynthetic seep environment off southern California and initial results indicated that this species was also utilizing methane-oxidizing bacterial symbionts as a potential food source. Dupont et al. (2013) describe a rich microbiome within Asbestopluma hypogea but no evidence of chemosynthetic symbionts was observed.

Reproduction for some cladorhizids has been elucidated from evidence based on morphological analysis or laboratory observation of collected specimens. For some, such as members of the genus Chondrocladia, spermatocyst or spermatophore production and release appears to occur only in inflated spheres of the aquiferous system whereas sperm capture and oocyte maturation occurs only in branch swellings (Kubler \& Barthel 1999; Lee et al. 2012). Cladorhiza pteron, a bilaterally symmetrical species, has distinct regions with spermatocyst production occurring only on the frontal side and oocyte development occurring on the abfrontal side (Reiswig \& Lee 2007). Typically lacking in aquiferous systems, the bundling of sperm into a spermatocyst or spermatphore aids in both the distribution and capture of sperm by nearby sponges and would also result in the observed simultaneous fertilization and synchronous development of oocytes (Riesgo et al. 2007). Spermatocysts are thought to be caught and incorporated into the sponges, similar to prey capture and phagocytosis (Riesgo et al. 2007). After release from the spermatocyst, the elongate and tailless sperm morphology enables the sperm to burrow into the dense sponge body tissue seeking out oocyte clusters (Riesgo et al. 2007). Chu and Reiswig (2014) describe a potential seasonality in reproduction for Asbestopluma occidentalis and the novel use of spontaneous destruction and reorganization of tissue as a necessity during larval release and a process that results in asexual budding.

Cladorhiza is a monophyletic genus within the Cladorhizidae with 41 described species, defined by the presence of trident anchorate anisochelae (Hestetun et al. 2016). Cladorhiza species are known to have arborescent, pinnate, flagelliform, crinorhiza (parasol), and stipitate morphologies (Boury-Esnault \& Rutzler 1997). They are known to have root-like rhizoids when living in soft sediment and disk-like holdfasts when attached to hard substrate.

With the increased use of technological tools such as manned submersibles and remotely operated vehicles (ROVs), recent expeditions to remote and far-flung locales such as the deep sea and polar regions have yielded numerous descriptions of beautiful and unexpected species within the Cladorhizidae including Cladorhiza corona (Lehnert et al. 2005), Cladorhiza pteron (Reiswig \& Lee 2007), Lollipocladia tiburoni (Vacelet 2008), Cercicladia australis (Rios et al. 2011), Chondrocladia lyra (Lee et al. 20012), Cladorhiza penniformis (Göcke \& Janussen 2013), Asbestopluma monticola (Lundsten et al. 2014) and many others. Here we describe three new species of parasol-shaped Cladorhiza collected by trawl and ROV from expeditions off California, USA, and the Gulf of California, Mexico, over a span of 46 years, with the first specimen being collected in 1969.

\section{Methods}

Specimens. Five specimens were collected using either a $25^{\prime}$ or $40^{\prime}$ otter trawl deployed from surface research vessels (Fig. 1). Remotely operated vehicles (ROVs) were used to videotape and collect six additional specimens using the ROV manipulator arm or high-flow suction sampler. Ten of these specimens were preserved and stored in $70 \%$ ethanol upon retrieval at the surface and, where noted, some were initially fixed in seawater formalin (SWF). One specimen was dried after retrieval. Prior to collection by ROV, specimens were filmed in situ using an Ikegami HDL-40 (ROV Doc Ricketts) or Panasonic WV-E550 (ROV Tiburon) video camera. At MBARI these video observations were merged with ancillary data so that latitude, longitude, depth, and CTD information is known for every observation and MBARI's Video Annotation and Reference System database (VARS, Schlining \& Jacobsen Stout, 2006) was queried for additional observations of these species. 
Spicule examination. Spicules from fragments of each body part were disassociated in concentrated nitric acid, rinsed, filtered, and mounted on glass microscope slides using the methods of Reiswig and Browman (1987). A compound microscope fitted with either a computer digitizer or calibrated digital still camera was used to measure the length and, where appropriate, the width of spicules for each spicule type within each body part of each species. Anomalies were noted but not enumerated. Immature spicules were deemed to be those of similar or lesser length than the mean length, but considerably thinner than the mean width.

For scanning electron microscopy (SEM), cleaned spicules were deposited onto membrane filters that were then taped to SEM stubs. Preparations were coated with gold-palladium and imaged with either a Hitachi S-3500N microscope (Hitachi High-Technologies Corp., Tokyo, Japan) at the University of Victoria, British Columbia, or a Hitachi S-3400N microscope (Hitachi High-Technologies Corp., Tokyo, Japan) at Moss Landing Marine Laboratories in California.

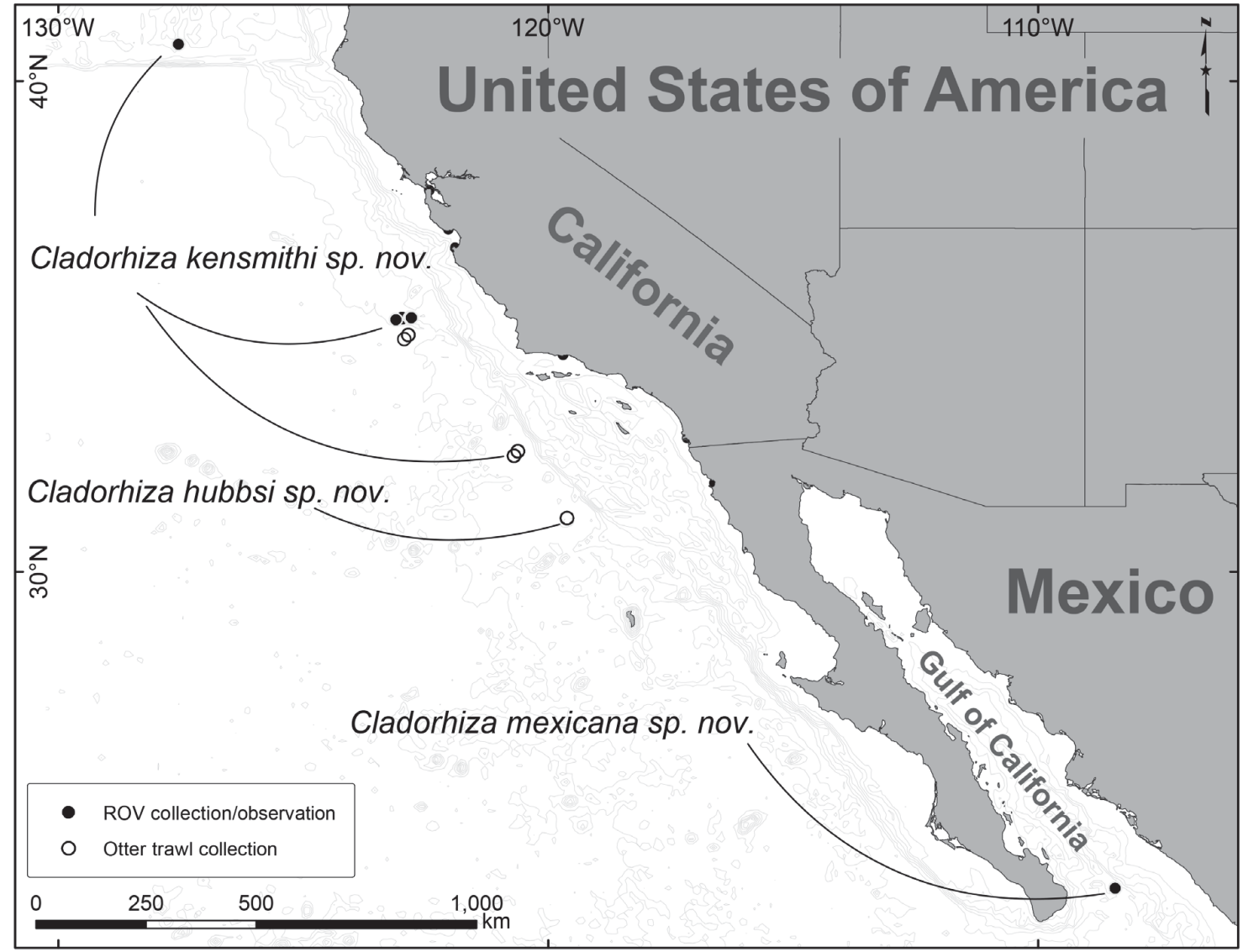

FIGURE 1. Map showing locations of collected species, $\bullet=$ ROV collections and observations, $\circ=$ trawl collections

\section{Systematics}

\section{Phylum Porifera Grant, 1836}

Class Demospongiae Sollas, 1885

Order Poecilosclerida Topsent, 1928

Family Cladorhizidae Dendy, 1922

Genus Cladorhiza Sars, 1872 
Type species: Cladorhiza abyssicola Sars, 1872.

Diagnosis: Cladorhizidae with only anchorate unguiferate anisochelae (Lopes \& Hajdu, 2013).

\section{Cladorhiza kensmithi sp. nov.}

Figs. 2-3, Table 1, Supplemental Table 1

Type material. Holotype: CASIZ Cat. No. 138573, Acc. No. 60917, MBARI-T199-A1, Gorda Ridge (40 45' 44.244" N, $127^{\circ} 32^{\prime}$ 48.2604" W, 3242 m), Northern California, USA, ROV Tiburon from R/V Western Flyer, originally fixed in 5\% SWF. Date of collection August 18, 2000; Paratype: CASIZ Cat. No. 219701, D231-As, Station M ( $\left.35^{\circ} 10^{\prime} \mathrm{N}, 122^{\circ} 59^{\prime} \mathrm{W}, 4000 \mathrm{~m}\right)$ ROV Doc Ricketts from R/V Western Flyer, Central California, USA, Date of collection May 25, 2011, 95\% ethanol; Other non-type specimens (Supplemental Table 1): Vicinity of Station M, Central California, USA ( $\left.35^{\circ} 10^{\prime} \mathrm{N}, 122^{\circ} 59^{\prime} \mathrm{W}\right)$, including CASIZ 219702 95\% ethanol, (MBARI D231a,b, ROV Doc Ricketts from R/V Western Flyer, May 25, 2011), CASIZ Cat. No. 219703 (MBARI T1143, ROV Tiburon from R/V Western Flyer, September 23, 2007) 95\% ethanol, CASIZ Cat. Nos. 119073 (Pulse 2, Sta. 216 M, 4100 m) fixed in 5\% SWF, 119072 (Pulse 25, Dive 2922, 4087 m) R/V New Horizon, 40' otter trawl, dry, west of Patton Escarpment, Southern California, USA; SCRIPPS Institute of Oceanography Benthic Invertebrate Collection Cat. Nos. P954 (MET Sta. 129, 3640 m), P970 (MET Sta. 133, 3689 m) R/V New Horizon, 40’ otter trawl, originally fixed in 5\% SWF.

Type locality. Holotype: Gorda Ridge, Northern California, USA, 40 45' 44.244" N, $127^{\circ} 32^{\prime} 48.2604^{\prime \prime}$ W, 3242 m; Paratype: Station M, Central California, USA, 35 $10^{\prime} \mathrm{N}, 122^{\circ} 59^{\prime} \mathrm{W}, 4000$ m; Additional non-type specimens: Vicinity of Station M, Central California, USA, $35^{\circ} 10^{\prime} \mathrm{N}, 122^{\circ} 59^{\prime} \mathrm{W}$.

Etymology. Named in honor of Dr. Kenneth L. Smith Jr. for contributions to marine biology and ecology over the course of a more than 40-year career in which he has devoted much of his expertise to studying extreme habitats, including the deep sea and polar regions, and the impacts of a changing climate on these ecosystems.

Diagnosis. Crinorhiza form, parasol-shaped sponge, on long stalk with densely branching rhizoid. Two to four apical spermatocyst-bearing discs on short, slender stalks. Four size classes of megasclere styles including rare strongyles and two microsclere categories including tridentate unguiferate anisochelae and contort sigmancistra.

Description. Holotype: CASIZ Cat. No. 138573 Large, parasol-shaped sponge $32.5 \mathrm{~cm}$ total length with four $10.5 \mathrm{~mm}$ long apical extensions ending in $3.8 \mathrm{~mm}$ diameter discs, which are densely packed with spermatocysts. Parasol is $2.7 \mathrm{~cm}$ in diameter with fifty-four $2.4-3.7 \mathrm{~cm}$ long filaments radiating in all directions. Stalk, which is broken, is $1-2.1 \mathrm{~mm}$ in width and ends in a terminal rhizoid $5.5 \mathrm{~cm}$ long and $2.6 \mathrm{~cm}$ wide. On the stalk, $7.5 \mathrm{~cm}$ below the parasol an oocyte-embryo swelling is present that is $1.9 \mathrm{~cm}$ long and 2.9 mm wide and contains numerous mature oocytes and embryos. Paratype: Large, parasol-shaped sponge $20.8 \mathrm{~cm}$ total length with two 9$11 \mathrm{~mm}$ long apical extensions ending in $4 \mathrm{~mm}$ diameter discs, which rise from a top-knot that is $7 \mathrm{~mm}$ above the apical surface of the parasol. Parasol is $1.9 \mathrm{~cm}$ in diameter with $1.6-5.5 \mathrm{~cm}$ long filaments radiating in all directions. Stalk is $1 \mathrm{~mm}$ in width and ends in a very bushy terminal rhizoid $4.65 \mathrm{~cm}$ long and $7 \mathrm{~cm}$ wide. On the stalk, $2.6 \mathrm{~cm}$ below the parasol an oocyte swelling is present which is $1.4 \mathrm{~cm}$ long and $2 \mathrm{~mm}$ wide and contains numerous mature oocytes and embryos. Preserved color yellowish-white, bright white in life.

Spicules (Table 1): Large style 1 length $3993.7 \pm 856.4 \mu \mathrm{m}, \mathrm{n}=161$, width $62.4 \pm 12.7 \mu \mathrm{m}, \mathrm{n}=114$; large style 2 length $1254.8 \pm 245.7 \mu \mathrm{m}, \mathrm{n}=378$, width $22.4 \pm 6.9 \mu \mathrm{m}, \mathrm{n}=248$; large style 3 length $345.6 \pm 105.2 \mu \mathrm{m}, \mathrm{n}=249$, width $14.9 \pm 2.1 \mu \mathrm{m}, \mathrm{n}=239$; strongyle length $722.2 \pm 301.2 \mu \mathrm{m}(\mathrm{n}=79)$, width $16.4 \pm 6.2 \mu \mathrm{m}(\mathrm{n}=57)$; tridentate unguiferate anisochelae $35.2 \pm 1.5 \mu \mathrm{m} n=366$; sigmancistra $46.5 \pm 3.0 \mu \mathrm{m}, \mathrm{n}=143$. Styles 1 occur mainly in the stalk but absent from antennae. Styles 2 occur everywhere but filaments. Styles 3 occur everywhere. Strongyles are present mainly in the root and less commonly in antenna stalks. Anisochelae cover all surfaces except the root and sigmancistras occur only in the antennae and antenna stalks. Paratype spicules: Large style 1 length $4867.2 \pm 891$ $\mu \mathrm{m}, \mathrm{n}=49$, width $67.8 \pm 17.8 \mu \mathrm{m}, \mathrm{n}=49$; large style 2 length $2567.4 \pm 565.2 \mu \mathrm{m}, \mathrm{n}=42$, width $50.3 \pm 19.6 \mu \mathrm{m}, \mathrm{n}=39$; large style 3 length $902 \pm 319.3 \mu \mathrm{m}, \mathrm{n}=48$, width $22.5 \pm 12.7 \mu \mathrm{m}, \mathrm{n}=46$; strongyle length $539.3 \pm 135.9 \mu \mathrm{m}, \mathrm{n}=55$, width $17.1 \pm 3.8 \mu \mathrm{m}, \mathrm{n}=55$; tridentate unguiferate anisochelae $37.8 \pm 1.5 \mu \mathrm{m} \mathrm{n}=27$; sigmancistra $52.2 \pm 6.6 \mu \mathrm{m}$, $\mathrm{n}=30$. Additional non-type specimen spicule measurements are listed in Supplemental Table 1. 

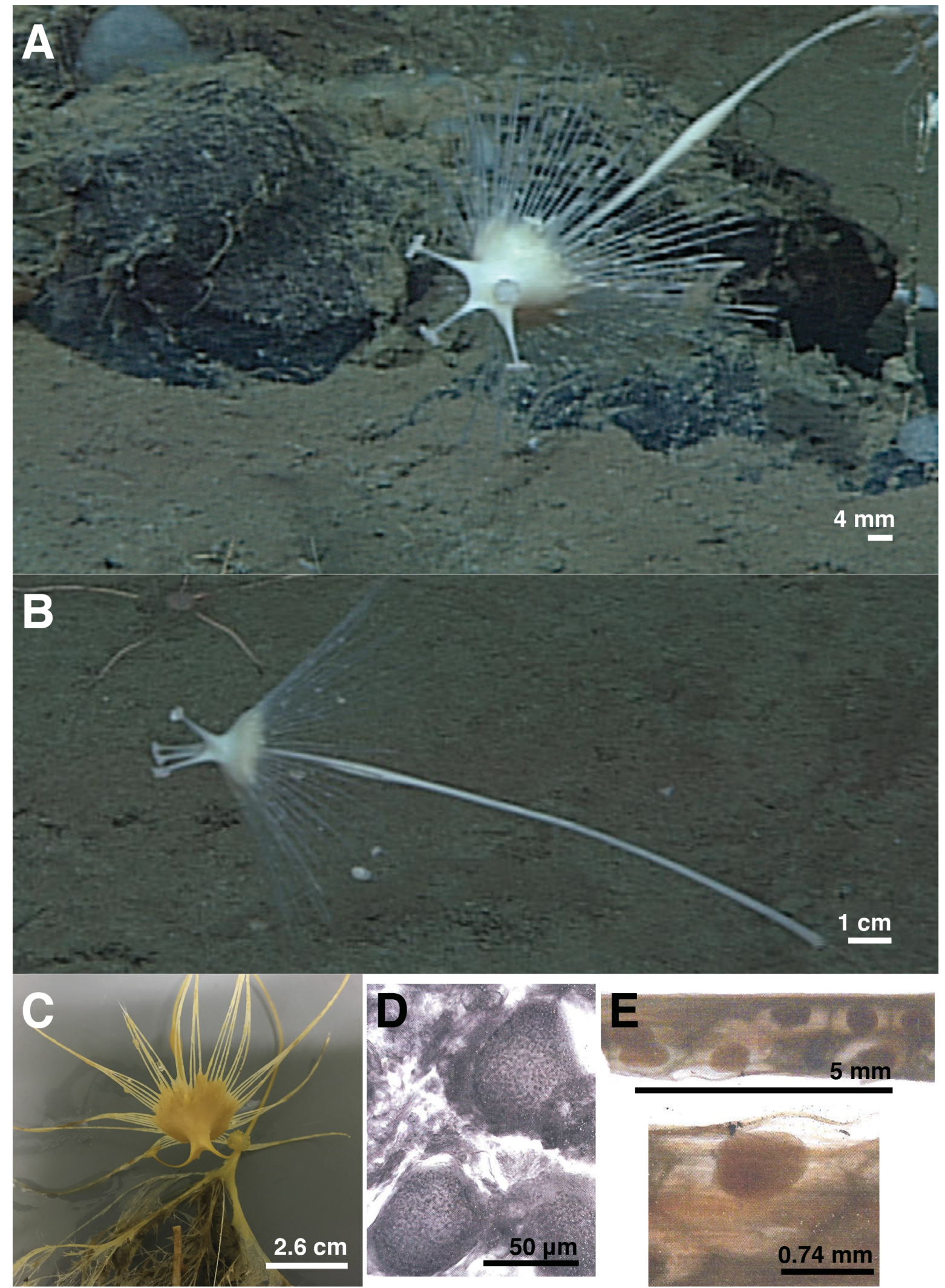

FIGURE 2. Cladorhiza kensmithi sp. nov. A, B) holotype in situ, C) preserved paratype, D) spermatocysts in apical disc of holotype, E) wide and close images of holotype oocyte swelling. 


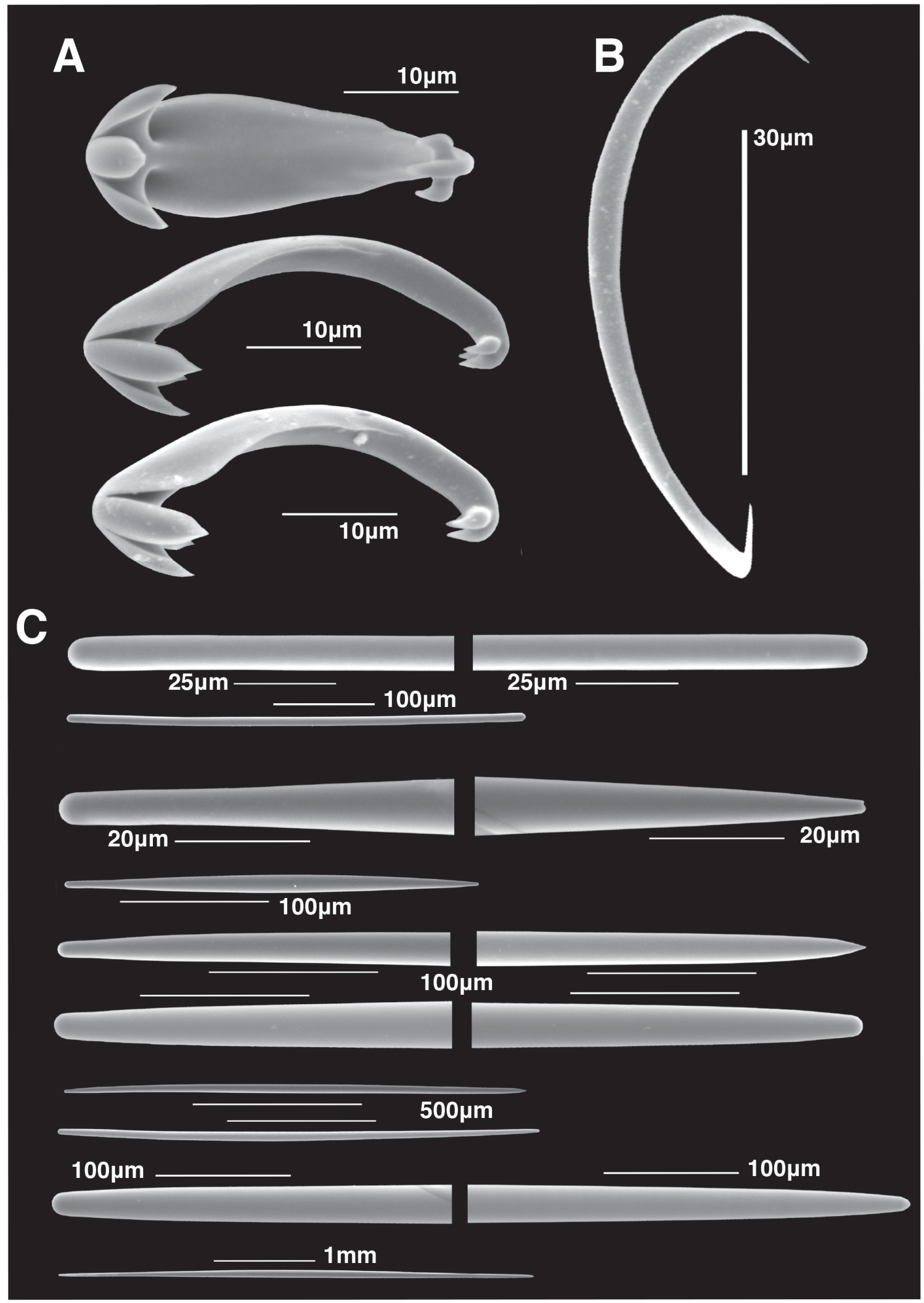

FIGURE 3. Cladorhiza kensmithi sp. nov. holotype SEM images of spicules A) tridentate unguiferate anisochelae, B) sigmancistra, C) strongyles and large styles of three size classes. 
Habitat and associated fauna. Station M is an abyssal long-term research study area located at $4100 \mathrm{~m}$ off central California (Smith and Druffel 1998). It is characterized as a low-relief, silty-clay sedimented habitat with no evidence of sedimentary input from turbidity currents or slumping from the continental shelf. It has been shown to have strong, seasonally variable surface productivity. Long-term studies at this station have demonstrated rapid seafloor community composition changes in response to surface productivity (Kuhnz et al. 2014). Video transects revealed that Cladorhiza kensmithi sp. nov. had variable densities of $0.022-0.097 / \mathrm{m}^{-2}$ between 2006 and 2012 . Distribution tended to be patchy, with apparent juvenile specimens clumped and attached to plate sponges (Bathydorus laniger and Docosaccus maculatus). This change in density over the sampling interval was attributed to increased surface productivity, which also accompanied a shift in community structure from a suspension-feeder to a deposit-feeder dominated community. Kuhnz et al. (2014) should be consulted for a detailed review of community constituents, structure, and changes over time at Station M.

Remarks. Of the parasol morphology Cladorhiza species, C. kensmithi sp. nov. differs from previously described species in morphology and spiculation, but most closely resembles C. corona, C. similis, and $C$. longipinna. Cladorhiza kensmithi sp. nov. differs from all of these species in its external morphology, specifically in its adult reproductive form, in having long apical extensions terminating in flattened discs. Although desilicification and thin sectioning was performed on one disc, we were unable to determine if the spermatocysts were organized into spermatophores before release.

\section{Cladorhiza mexicana sp. nov.}

Figs. 4-5, Table 1

Type material. Holotype: CASIZ Cat. No. 219700, MBARI D741-A1, Alarcon Rise, Gulf of California, Mexico, $23^{\circ} 32^{\prime} 40.7682^{\prime \prime}$ N, $108^{\circ} 25^{\prime} 52.7304^{\prime \prime}$ W, 2473 m, ROV Doc Ricketts dive 741 from R/V Western Flyer. Date of collection April 5, 2015. Fixed in 95\% ethanol.

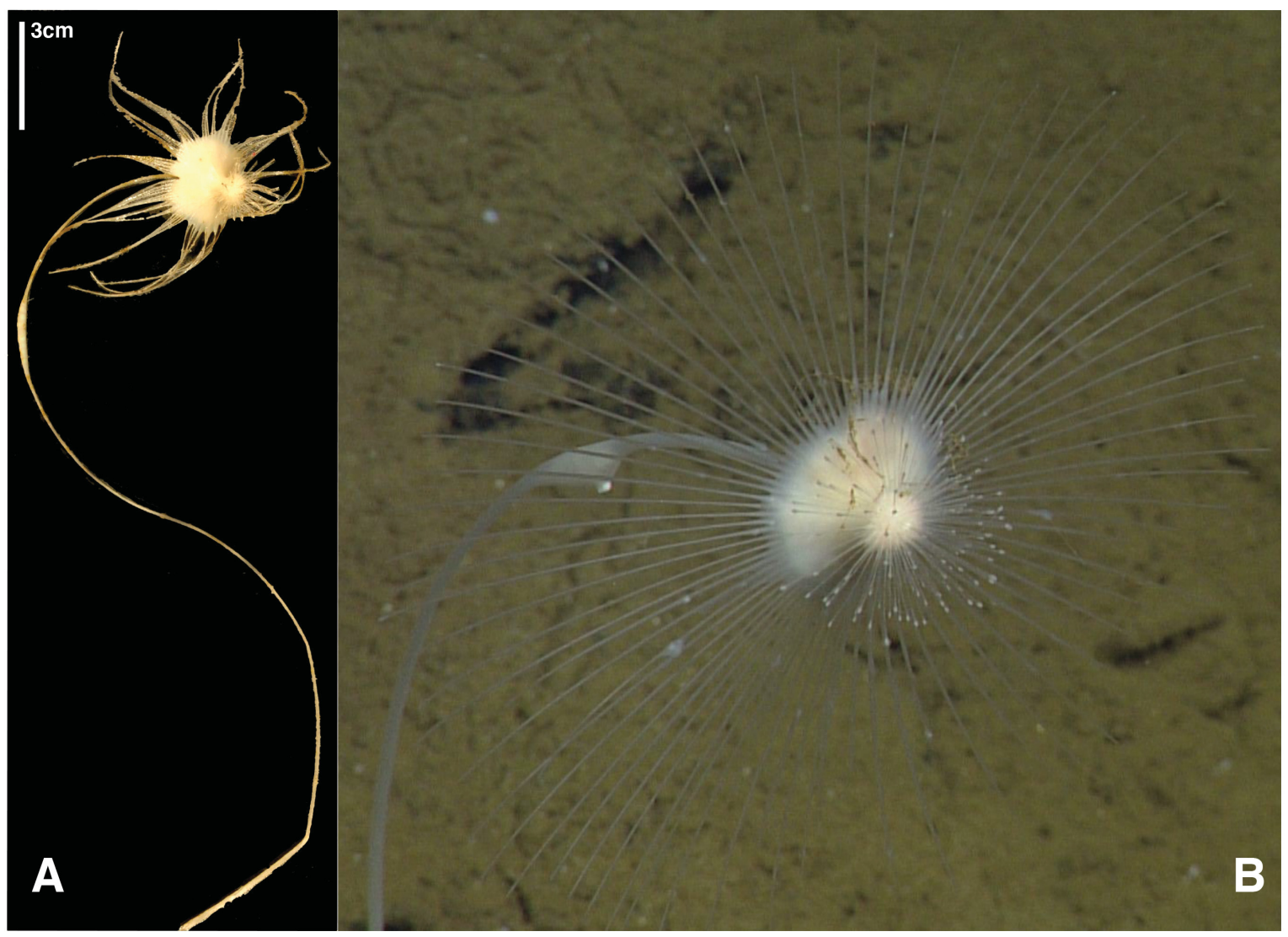

FIGURE 4. Cladorhiza mexicana sp. nov. A) preserved holotype and B) holotype in situ before collection. 


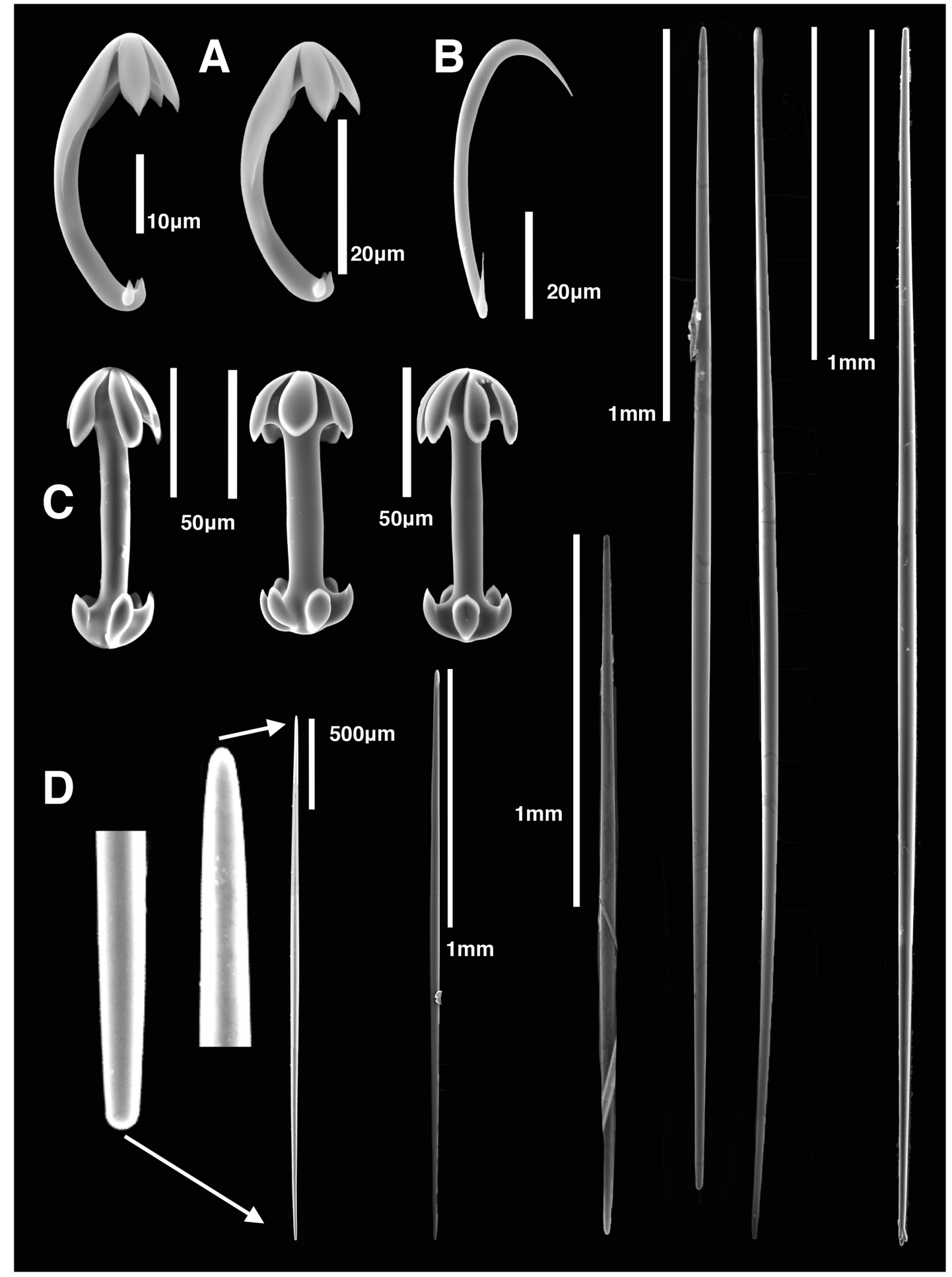

FIGURE 5. Cladorhiza mexicana sp. nov. SEM images of spicules including A) tridentate unguiferate anisochelae, B) sigmancistra, C) asymmetrical pseudoamphiasters, D) large styles in three size classes. 
Type locality. Alarcon Rise, Gulf of California, Mexico.

Etymology. The species name, mexicana, alludes to the country where the holotype was discovered.

Diagnosis. Crinorhiza form, parasol-shaped sponge, on long stalk and presumed basal holdfast. Three size classes of megasclere styles and three microsclere categories including tridentate unguiferate anisochelae, contort sigmancistras, and asymmetrical pseudoamphiasters.

Description. Holotype: Long, parasol-shaped sponge measuring $30 \mathrm{~cm}$ in total length with a stalk width of 1 $\mathrm{mm}$. Parasol diameter of $2.6 \mathrm{~cm}$ with seventy-six long filaments, $3.3-4.2 \mathrm{~cm}$ in length, radiating out in all directions from the parasol edge. Spheroid top-knot on apical surface of parasol measures $9 \mathrm{~mm}$ in length and 7.3 $\mathrm{mm}$ in diameter with dense, small filaments radiating in all directions in lengths from 4-9 mm. On the stalk $6.9 \mathrm{~cm}$ below the parasol is an oocyte swelling, containing numerous visible oocytes, $2.5 \mathrm{~cm}$ in length and $3 \mathrm{~mm}$ at its widest dimension. Basal holdfast (presumed) broke off during collection. Creamy yellow in preserved state, bright white living specimen.

Spicules. Large style 1 length $3845 \pm 268 \mu \mathrm{m}, \mathrm{n}=46$, width $66.5 \pm 7.3 \mu \mathrm{m}, \mathrm{n}=46$; large style 2 length $2948 \pm$ $298 \mu \mathrm{m}, \mathrm{n}=39$, width $54.2 \pm 8.9 \mu \mathrm{m}, \mathrm{n}=40$; large style 3 length $1612.3 \pm 319 \mu \mathrm{m}, \mathrm{n}=46$, width $31.4 \pm 7.4 \mu \mathrm{m}, \mathrm{n}=44$; tridentate unguiferate anisochelae $34.5 \pm 1.5 \mu \mathrm{m}, \mathrm{n}=67$; pseudoamphiaster with 5 alae each side, alae slightly longer on one end $108.8 \pm 6.4 \mu \mathrm{m}, \mathrm{n}=53$; sigmancistra $51.2 \pm 3.8 \mu \mathrm{m}, \mathrm{n}=58$ and occur only in the apical surfaces and small filaments of the parasol.

Habitat and associated fauna. The holotype was collected from a pillow basalt with a thin sediment veneer in a heterogeneous habitat of pillow basalt interspersed with sedimentary deposits. The covering of sediment was thick enough to conceal the mode of basal attachment of the holotype, however, upon retrieval, the base of the specimen broke and we interpret this as evidence of basal holdfast attachment, as has been observed for other hard rock attached species. In addition, when rooted in the sediment with rhizoids, these sponges generally release quite easily and are retrieved intact by ROV manipulator or trawl. Other taxa observed in low abundance in the vicinity of the holotype include Actiniaria, Aldrovandia sp., Bonellidae, Galatheidae, Heteropolypus ritteri, Laetmogonidae, Lycenchelys sp., Megalodicopia hians, Ophidiidae, Peniagone sp., and Xenophyophoroidea.

Remarks. Of the 43 previously described species of Cladorhiza, very few have been described that have the parasol morphology of the species described herein. Those Cladorhiza species that are most similar include $C$. corona Lehnert et al., 2005, C. longipinna Ridley \& Dendy, 1886, and C. mirabilis Ridley \& Dendy, 1886. Cladorhiza corona is quite distinct and differs from C. mexicana sp. nov. both in having the 'crown' morphology and in lacking pseudoamphiasters. Cladorhiza longipinna differs morphologically and in its lack of pseudoamphiasters. Cladorhiza mirabilis was described from a specimen collected in the South Pacific and its description differs greatly both in size and spiculation. For example, Cladorhiza mirabilis has a longitudinal length (measured from end to end of parasol edge filament) of $6 \mathrm{~mm}$, whereas this longitudinal length on C. mexicana is $\sim 8.8 \mathrm{~cm}$. Similar to C. mexicana sp. nov., C. mirabilis does have pseudoamphiasters but they are of a much larger size (230 $\mu \mathrm{m}$ in C. mirabilis vs. $109 \mu \mathrm{m}$ in C. mexicana sp. nov.). Pseudoamphiasters in C. mirabilis also appear to be symmetrical with alae length on each end of the pseudoamphiasters being equal whereas they appear asymmetrical in C. mexicana sp. nov. owing to the difference in alae length on each side. In general, sigmas appear to be larger in C. mirabilis as well. Finally, C. mexicana sp. nov. was collected from basaltic pillow lavas and, presumably, was attached via a holdfast disc whereas $C$. mirabilis was retrieved from abyssal sediments and has root-like rhizoids as its point of attachment.

\section{Cladorhiza hubbsi p. nov.}

Figs. 6, Table 1.

Type material. Holotype: SCRIPPS Institute of Oceanography Benthic Invertebrate Collection, Cat. No. P675, Acc. No. 1969.003, Station MV69-VI-9, West of Patton Escarpment (31.2 N, 119.6167 ${ }^{\circ}$ W, $\left.3600 \mathrm{~m}\right)$, Southern California, USA, R/V Melville using 25' otter trawl. Date of collection December 18, 1969. Fixed in 5\% SWF.

Etymology. Named in honor of Dr. Carl Leavitt Hubbs, renowned ichthyologist who studied both freshwater and marine fishes and had a keen interest in zoogeography, biology, hybridization, taxonomy, ocean temperature paleo-history, and more. Dr. Hubbs had an amazingly productive career, with nearly 712 publications to his credit with considerable emphasis placed on educating the public and actively promoting conservation. 


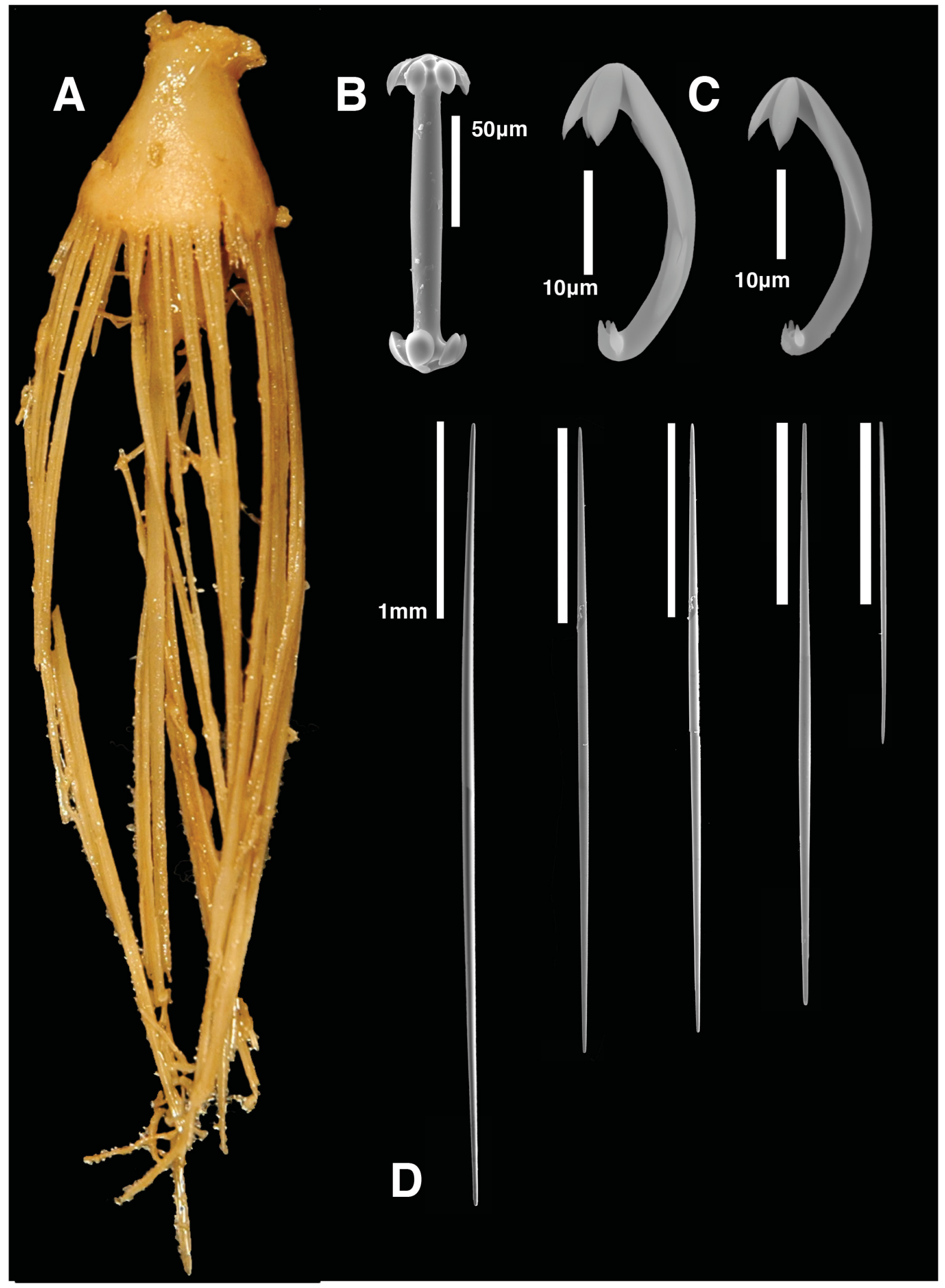

FIGURE 6. Cladorhiza hubbsi sp. nov. A) preserved specimen and SEM images of spicules including B) symmetrical pseudoamphiaster, C) tridentate unguiferate anisochelae, D) large styles in three size classes. 
TABLE 1. Spicule measurements for three new species of Cladorhiza from the Northeast Pacific. Number of spicules measured (n), average length (L) and width (W, where available) in $\mu \mathrm{m} \pm$ standard deviation are shown.

\begin{tabular}{|c|c|c|c|}
\hline Specimen & Large style 1 & Large style 2 & Large style 3 \\
\hline Cladorhiza kensmithi sp. nov. & L $3993.7 \pm 856.4 \mu \mathrm{m}(\mathrm{n}=161)$ & $\mathrm{L} 1254.8 \pm 245.7 \mu \mathrm{m}(\mathrm{n}=378)$ & $\mathrm{L} 345.6 \pm 105.2 \mu \mathrm{m}(\mathrm{n}=249)$ \\
\hline Holotype & $\mathrm{W} 62.4 \pm 12.7 \mu \mathrm{m}(\mathrm{n}=114)$ & W $22.4 \pm 6.9 \mu \mathrm{m}(\mathrm{n}=248)$ & W $14.9 \pm 2.1 \mu \mathrm{m}(\mathrm{n}=239)$ \\
\hline Cladorhiza kensmithi sp. nov. & $\mathrm{L} 4867.2 \pm 891 \mu \mathrm{m}(\mathrm{n}=49)$ & $\mathrm{L} 2567.4 \pm 565.2 \mu \mathrm{m}(\mathrm{n}=42)$ & $\mathrm{L} 902 \pm 319.3 \mu \mathrm{m}(\mathrm{n}=48)$ \\
\hline Paratype & W $67.8 \pm 17.8 \mu \mathrm{m}(\mathrm{n}=49)$ & W $50.3 \pm 19.6 \mu \mathrm{m}(\mathrm{n}=39)$ & W $22.5 \pm 12.7 \mu \mathrm{m}(\mathrm{n}=46)$ \\
\hline \multirow[t]{2}{*}{ Cladorhiza mexicana sp. nov. } & L $3845 \pm 268 \mu \mathrm{m}(\mathrm{n}=46)$ & $\mathrm{L} 2948 \pm 298 \mu \mathrm{m}(\mathrm{n}=39)$ & L $1612.3 \pm 319 \mu \mathrm{m}(\mathrm{n}=46)$ \\
\hline & $\mathrm{W} 66.5 \pm 7.3 \mu \mathrm{m}(\mathrm{n}=46)$ & W $54.2 \pm 8.9 \mu \mathrm{m}(\mathrm{n}=40)$ & $\mathrm{W} 31.4 \pm 7.4 \mu \mathrm{m}(\mathrm{n}=44)$ \\
\hline \multirow[t]{2}{*}{ Cladorhiza hubbsi sp. nov. } & $\mathrm{L} 5067 \pm 769.1 \mu \mathrm{m}(\mathrm{n}=53)$ & $\mathrm{L} 4172.3 \pm 460.4 \mu \mathrm{m}(\mathrm{n}=45)$ & $\mathrm{L} 2565.1 \pm 467.8 \mu \mathrm{m}(\mathrm{n}=83)$ \\
\hline & $\mathrm{W} 70.48 \pm 9.4 \mu \mathrm{m}(\mathrm{n}=93)$ & $\mathrm{W} 61.5 \pm 18.2 \mu \mathrm{m}(\mathrm{n}=44)$ & $\mathrm{W} 44.1 \pm 14.8 \mu \mathrm{m}(\mathrm{n}=83)$ \\
\hline \multicolumn{4}{|l|}{ Continued } \\
\hline Strongyle & Amphiaster & Sigmancistra & Anisochelae \\
\hline $\mathrm{L} 722.2 \pm 301.2 \mu \mathrm{m}(\mathrm{n}=79)$ & & $\mathrm{L} 46.5 \pm 3.0 \mu \mathrm{m}(\mathrm{n}=143)$ & $\mathrm{L} 35.2 \pm 1.5 \mu \mathrm{m}(\mathrm{n}=366)$ \\
\hline \multicolumn{4}{|l|}{$\mathrm{W} 16.4 \pm 6.2 \mu \mathrm{m}(\mathrm{n}=57)$} \\
\hline L $539.3 \pm 135.9 \mu \mathrm{m}(\mathrm{n}=55)$ & & $\mathrm{L} 52.2 \pm 6.6 \mu \mathrm{m}(\mathrm{n}=30)$ & $\mathrm{L} 37.8 \pm 1.5 \mu \mathrm{m}(\mathrm{n}=27)$ \\
\hline \multicolumn{4}{|l|}{$\mathrm{W} 17.1 \pm 3.8 \mu \mathrm{m}(\mathrm{n}=55)$} \\
\hline & $\mathrm{L} 108.8 \pm 6.4 \mu \mathrm{m}(\mathrm{n}=53)$ & $\begin{array}{l}\text { L sigmancistra } 51.2 \pm 3.8 \mu \mathrm{m} \\
\qquad(\mathrm{n}=58)\end{array}$ & $\mathrm{L} 34.5 \pm 1.5 \mu \mathrm{m}(\mathrm{n}=67)$ \\
\hline & $\mathrm{L} 136.2 \pm 7.8 \mu \mathrm{m}(\mathrm{n}=48)$ & $\mathrm{L}$ sigmancistra $94 \pm 8.8 \mu \mathrm{m}(\mathrm{n}=87)$ & $\mathrm{L} 31.4 \pm 1.8 \mu \mathrm{m}(\mathrm{n}=57)$ \\
\hline
\end{tabular}

Diagnosis. Crinorhiza form, very conical, parasol-shaped sponge, on stalk of unknown true length. Three size classes of megasclere styles and three microsclere categories including tridentate unguiferate anisochelae, contort sigmancistra, and pseudoamphiaster.

Description. Holotype: Deeply conical parasol form, with a flat-topped parasol apex. Apex measures $7 \mathrm{~mm}$ in diameter. At its widest point in cross section the parasol, excluding filaments, is $1.1 \mathrm{~cm}$ in diameter, parasol edge filaments are numerous and surround the parasol, measuring $4.1-5.1 \mathrm{~cm}$ in length. Stalk is broken and measures 3.5 $\mathrm{cm}$ in length and $1.1 \mathrm{~mm}$ wide. Total length is $6.6 \mathrm{~cm}$, however, attachment base is broken off so neither total length nor attachment type are known. Just below the parasol/stalk junction is a large, ovoid swelling that is $8 \mathrm{~mm}$ long and $5 \mathrm{~mm}$ in diameter. Brownish-yellow in preserved state.

Spicules. Large style 1 length $5067 \pm 769.1 \mu \mathrm{m}, \mathrm{n}=53$, width $70.48 \pm 9.4 \mu \mathrm{m}, \mathrm{n}=93$; large style 2 length 4172.3 $\pm 460.4 \mu \mathrm{m}, \mathrm{n}=45$, width $61.5 \pm 18.2 \mu \mathrm{m}, \mathrm{n}=44$; large style 3 length $2565.1 \pm 467.8 \mu \mathrm{m}, \mathrm{n}=83$, width $44.1 \pm 14.8$ $\mu \mathrm{m}, \mathrm{n}=83$; tridentate unguiferate anisochelae $31.4 \pm 1.8 \mu \mathrm{m}, \mathrm{n}=57$; pseudoamphiaster with 4-6 alae (most often 5) $136.2 \pm 7.8 \mu \mathrm{m}, \mathrm{n}=48$; sigmancistra $94 \pm 8.8 \mu \mathrm{m}, \mathrm{n}=87$ and these occur only in the apical surfaces of the parasol.

Habitat and associated fauna. Trawled specimen, no additional information provided.

Remarks. Cladorhiza hubbsi sp. nov. differs from Cladorhiza corona (Lehnert et al., 2005) and C. longipinna (Ridley \& Dendy, 1886) in both morphology and presence of pseudoamphiasters, as described above for $C$. mexicana sp. nov. Likewise, Cladorhiza mirabilis Ridley \& Dendy, 1886 differs from C. hubbsi sp. nov. in both size and spiculation. For example, Cladorhiza mirabilis has a longitudinal length of $6 \mathrm{~mm}$, yet parasol filament 
length alone measures $4.2-5.1 \mathrm{~cm}$ in $C$. hubbsi sp. nov. and parasol edge to edge, excluding filaments measures 1.1 $\mathrm{cm}$. In addition, the parasol is deeply conical, with parasol edge filaments pointing downward, nearly perpendicular to the stalk axis and less obliquely than that described for C. mirabilis. Cladorhiza mirabilis does have pseudoamphiasters but they are of a much larger size (230 $\mu \mathrm{m}$ in C. mirabilis vs. $136 \mu \mathrm{m}$ in C. hubbsi sp. nov.). Pseudoamphiasters in C. mirabilis and C. hubbsi sp. nov. appear to be symmetrical with alae length on each end of the pseudoamphiasters being equal in length on each side. Large styles in $C$. hubbsi sp. nov. are found in three size classes and the largest size class is considerably larger than those listed for C. mirabilis (5067 $\mu \mathrm{m}$ in C. hubbsi sp. nov. vs. $\sim 3500 \mu \mathrm{m}$ in C. mirabilis). Anisochelae are smaller in C. hubbsi sp. nov. (38 $\mu \mathrm{m}$ in C. mirabilis vs. 31.4 $\mu \mathrm{m}$ in $C$. hubbsi sp. nov.). In general, sigmancistra appear to be larger in $C$. hubbsi sp. nov. as well (94 $\mu \mathrm{m}$ in $C$. hubbsi sp. nov. vs. $76 \mu \mathrm{m}$ in C. mirabilis). Brownish-yellow in preserved state.

\section{Discussion}

The three species of Cladorhiza described here increase the number of known Cladorhiza species in the Northeast Pacific to six. Previous to these new descriptions, three other Cladorhiza species had been described for the Northeast Pacific, including C. pteron (Reiswig \& Lee, 2007), C. caillieti (Lundsten et al., 2014), and C. evae (Lundsten et al., 2014). Several other species of Cladorhiza have been described from regions just beyond the marine region considered as the Northeast Pacific, including C. corona (Lehnert et al., 2005) from the Aleutian Islands, C. linearis (Ridley \& Dendy, 1886) Panama to central South Pacific, C. longipinna (Ridley \& Dendy, 1886) off Hawaii, and C. rectangularis (Ridley \& Dendy 1886) north central Pacific, south of Aleutian Islands.

Of all previously described Cladorhiza species, few have the parasol form, alluded to in Ridley \& Dendy (1886) as belonging to a morphologically similar grouping cladorhizids called the 'crinorhiza.' It appears as if the 'crinorhiza' form, as described, encompassed several cladorhizid genera with morphologies that including spheroid, cup, parasol, and cylindrical forms with radiating or projecting filaments, situated at the top end of a long, slender stalk. We have purposely used 'parasol' form in our descriptions to refer to their distinct morphologies which strikingly resemble true parasols and have, in adult form, numerous, basally directed, long filaments radiating in all directions from the parasol edge. Other described species that have the parasol form include Cladorhiza mirabilis, C. longipinna, and C. similis (Ridley \& Dendy, 1886) and C. corona (Lehnert et al., 2005). It is worth noting that Ridley \& Dendy (1886) postulated that the basally directed filaments were supportive structures, used to keep the top of the crinorhiza forms elevated above the sediments. However, this was never observed in our in situ observations and we, therefore, must reject that hypothesis. Cladorhiza mirabilis (Ridley \& Dendy 1886), Cladorhiza hubbsi sp. nov. and Cladorhiza mexicana sp. nov. are the only Cladorhiza species known to have pseudoamphiaster (Hadju \& Vacelet 2002) spicules and in C. mexicana sp. nov. these appear to be asymmetrical, with longer alae on one end, which is quite different from those found in C. mirabilis (Ridley \& Dendy, 1886), and C. hubbsi sp. nov.

The long, radiating filaments that emanate from the parasol edge appear to be used in prey capture as numerous encysted prey were observed on those filaments. Ridley \& Dendy (1886) described these radiating filaments as being used to prop the sponge upon or above the surface of the sediments, however, during numerous in situ encounters we observed that the stalk is held quite erect, keeping the parasol and filaments well above the seafloor.

Multiple collected specimens and video observations of Cladorhiza kensmithi sp. nov. yield information about variation in morphology, spiculation, and spicule size classes. Ontogenetic shifts in C. kensmithi sp. nov. morphology are apparent with the adult forms, as seen in the holotype and paratype, complete with apical antennae discs, which appear to be locations of spermatocyst production and release. These mature forms also housed oocytes and embryos within oocyte swellings on stalks below the parasol. Juvenile specimens did not have apical antenna discs or oocyte stalk swellings. Additionally, juvenile parasols appear to be laterally compressed, and radiating filaments are few and underdeveloped, or completely absent. Spiculation appears to change with maturation as well, such that spicule sizes in each size class generally increase and sigmancistra are present only in larger or fully mature specimens.

Cladorhiza kensmithi sp. nov. lives on the abyssal plain, in soft, clay-rich sediments in very low densities which have been reported to vary in response to changes in surface primary productivity (Kuhnz et al. 2014). Video observations of this species number into the thousands and, based on those observations and collected specimens, 
we have determined that the juveniles regularly settle on plate sponges and are often clumped. Adults are typically found individually and not as commonly associated with plate sponges. The ecological setting where Cladorhiza hubbsi sp. nov. was collected is likely similar to that of $C$. kensmithi sp. nov., but is ultimately unknown due to its collection method. C. mexicana sp. nov. was collected from a basaltic lava in the Gulf of California, Mexico, that was covered with a thin sediment veneer which precluded observation of the basal attachment structure, however, based on the evidence it was likely a basal holdfast disc. Other individuals of $C$. mexicana sp. nov. were observed in this habitat but no additional specimens were collected and quantitative data are not available to estimate abundance. Qualitative video observations show a sparse, non-clumped distribution.

With the advancement of remote sampling technology increasing access to more and more remote habitats our knowledge of the life that exists in these locations is expanding at a rapid rate. It is only now, aided by this technology, that we are able to understand more about the biology and ecology of these unique organisms through in situ observations of habitat preferences, predator-prey interaction, reproduction, and geographic distribution. Future research should focus on determining feeding, growth, and reproduction processes, especially in Cladorhiza kensmithi sp. nov., where a plentiful population of specimens and opportunities for regular sampling at Station M would yield a wealth of novel information.

\section{Acknowledgements}

We are grateful for support from the pilots of the ROVs Doc Ricketts and Tiburon and the crew of the R/V Western Flyer. We thank D. Clague and K. Smith for use of video observations and collected specimens. We thank S. Tanner and K. Schlining for technical support. C. Piotrowski and G. Rouse provided assistance in retrieving museum specimens. We appreciate the comments from anonymous reviewers who greatly improved this manuscript. The David and Lucile Packard Foundation's funding of MBARI supported this work. Collection of some specimens was also supported by NSF grant OCE 92-17334 to K. Smith.

\section{References}

Boury-Esnault, N. \& Rützler, K. (1997) Thesaurus of Sponge Morphology. Smithsonian Contributions to Zoology Number 596. Smithsonian Institution Press, Washington, D.C., pp. 1-55. https://doi.org/10.5479/si.00810282.596

Chu, J.W.F. \& Reiswig, H.M. (2014) Mechanisms of propagule release in the carnivorous sponge Asbestopluma occidentalis. Invertebrate Biology, 133, 109-120. https://doi.org/10.1111/ivb.12045

Dendy, A. (1922) Report on the Sigmatotetraxonida collected by H.M.S. Sealark in the Indian Ocean. No. I.- The Percy Sladen Trust Expedition to the Indian Ocean in 1905, under the Leadership of Mr. J. Stanley Gardiner, M.A. Vol. VII. No. I. Transactions of the Linnean Society of London, Series 2, Zoology, 18, 1-164. https://doi.org/10.1111/j.1096-3642.1922.tb00547.x

Dupont, S., Corre, E., Li, Y., Vacelet, J. \& Bourguet-Kondracki, M.L. (2013) First insights into the microbiome of a carnivorous sponge. FEMS Microbiology Ecology, 86, 520-531. https://doi.org/10.1111/1574-6941.12178

Göcke, C. \& Janussen, D. (2013) Demospongiae of ANT XXIV/2 (SYSTCO I) Expedition-Antarctic Eastern Weddell Sea. Zootaxa, 3692 (1), 28-101. https://doi.org/10.11646/zootaxa.3692.1.6

Grant, R.E. (1836) Animal Kingdom. In: Todd, R.B. (Ed.), The Cyclopaedia of Anatomy and Physiology. Vol. 1. Sherwood, Gilbert \& Piper, London, pp. 107-118.

Hajdu, E. \& Vacelet, J. (2002) Family Cladorhizidae. In: Hooper, J.N.A., van Soest, R.W.M. (Eds.), Systema Porifera: a guide to the classification of sponges. Vol. 1. Kluwer Academic/Plenum Publishers, New York, pp. 636-641. https://doi.org/10.1007/978-1-4615-0747-5_68

Hestetun, J.T., Vacelet, J., Boury-Esnault, N., Borchiellini, C., Kelly, M., Rios, P., Cristobo, J. \& Rapp, H.T. (2016) The systematics of carnivorous sponges. Molecular Phylogenetics and Evolution, 94, 327-345. https://doi.org/10.1016/j.ympev.2015.08.022

Kubler, B. \& Barthel, D. (1999) A carnivorous sponge, Chondrocladia gigantea (Porifera: Demospongiae: Cladorhizidae), the giant deep-sea clubsponge from the Norwegian Trench. Memoirs of the Queensland Museum, 44, 289-297.

Kuhnz, L.A., Ruhl, H.A., Huffard, C.L. \& Smith Jr., K.L. (2014) Rapid changes and long-term cycles in the benthic megafaunal community observed over 24 years in the abyssal northeast Pacific. Progress in Oceanography, $124,1-11$. 
https://doi.org/10.1016/j.pocean.2014.04.007

Lee, W.L., Reiswig, H.M., Austin, W.C. \& Lundsten, L. (2012) An extraordinary new carnivorous sponge, Chondrocladia lyra, in the new subgenus Symmetrocladia (Demospongiae, Cladorhizidae), from off of northern California, USA. Invertebrate Biology, 131 (4), 259-284.

http://dx.doi.org/10.1111/ivb.12001

Lehnert, H., Watling, L. \& Stone, R. (2005) Cladorhiza corona sp. nov. (Porifera: Demospongiae: Cladorhizidae) from the Aleutian islands (Alaska). Journal of the Marine Biological Association of The United Kingdom, 85, 1359-1366. https://doi.org/10.1017/S0025315405012531

Leys, S.P., Yahel, G., Reidenbach, M.A., Tunnicliffe, V., Shavit, U. \& Reiswig, H.M. (2011) The sponge pump: the role of current induced flow in the design of the sponge body plan. PLoS ONE, 6 (12), e27787. https://doi.org/10.1371/journal.pone.0027787

Lundsten, L., Reiswig, H.M. \& Austin, W.C. (2014) Four new species of Cladorhizidae (Porifera, Demospongiae, Poecilosclerida) from the Northeast Pacific. Zootaxa, 3786 (2), 101-123. https://doi.org/10.11646/zootaxa.3786.2.1

Reiswig, H.M. \& Browman, H.I. (1987) Use of membrane filters for microscopic preparations of sponge spicules. Transactions of the American Microscopical Society, 106 (1), 10-20. https://doi.org/10.2307/3226280

Reiswig, H.M. \& Lee, W.L. (2007) A new species of Cladorhiza (Porifera: Cladorhizidae) from S. California (USA). In: Custódio, M.R., Lôbo-Hajdu, G., Hajdu, E. \& Muricy, G. (Eds.), Porifera Research: Biodiversity, Innovation and Sustainability. Museu Nacional, Rio de Janeiro, pp. 517-523.

Ridley, S.O. \& Dendy, A. (1887) Report on the Monaxonida collected by H.M.S. 'Challenger' during the years $1873-1876$. Report on the Scientific Results of the Voyage of H.M.S. 'Challenger', 1873-1876 Zoology, 20 (59), 1-275.

Riesgo, A., Taylor, C. \& Leys, S.P. (2007) Reproduction in a carnivorous sponge: the significance of the absence of an aquiferous system in the sponge body plan. Evolution \& Development, 9, 618-631. https://doi.org/10.1111/j.1525-142X.2007.00200.x

Rios, P., Kelly, M. \& Vacelet, J. (2011) Cercicladia australis, a new carnivorous sponge with novel chelae from the Tasman Basin and the Argentine Patagonian Margin (Porifera, Cladorhizidae). Zootaxa, 3131 (1), 52-62. https://doi.org/10.11646/zootaxa.3131.1.3

Sars, G.O. (1872) On some remarkable forms of animal life from the great deeps off the Norwegian coast. I. Partly from posthumous manuscripts of the late professor Dr. Michael Sars. Brøgger \& Christie, Christiania, pp. 62-82. http://dx.doi.org/10.5962/bhl.title.11274

Schlining, B. \& Jacobsen Stout, N. (2006) MBARI's video annotation and reference system. Proceedings of the Marine Technology Society/Institute of Electrical and Electronics Engineers Oceans Conference, Boston, 2006, pp. 1-5. https://doi.org/10.1109/oceans.2006.306879

Smith Jr., K.L. \& Druffel, E. (1998) Long time-series monitoring of an abyssal site in the NE Pacific: an introduction. DeepSea Research Part II, 45, 573-586. https://doi.org/10.1016/S0967-0645(97)00094-5

Sollas, W.J. (1885b) A Classification of the Sponges. Annals and Magazine of Natural History, Series 5, 16 (95), 395.

Topsent, E. (1928) Spongiaires de l'Atlantique et de la Méditerranée provenant des croisières du Prince Albert ler de Monaco. Résultats des campagnes scientifiques accomplies par le Prince Albert I. Monaco, 74, 1-376.

Vacelet, J. (2006) New carnivorous sponges (Porifera, Poecilosclerida) collected from manned submersibles in the deep Pacific. Zoological Journal of the Linnean Society, 148, 553-584. http://dx.doi.org/10.1111/j.1096-3642.2006.00234.x

Vacelet, J. (2008) A new genus of carnivorous sponges (Porifera: Poecilosclerida, Cladorhizidae) from the deep N-E Pacific, and remarks on the genus Neocladia. Zootaxa, 1752, 57-65.

Vacelet, J. \& Boury-Esnault, N. (1995) Carnivorous sponges. Nature, 373 (6512), 333-335 https://doi.org/10.1038/373333a0

Vacelet, J. \& Duport, E. (2004) Prey capture and digestion in the carnivorous sponge Asbestopluma hypogea (Porifera: Demospongiae). Zoomorphology, 123 (4), 179-190 https://doi.org/10.1007/s00435-004-0100-0

Vacelet, J., Kelly, M. \& Schlacher-Hoenlinger, M. (2009) Two new species of Chondrocladia (Demospongiae:Cladorhizidae) with a new spicule type from the deep South Pacific, and a discussion of the Genus Meliiderma. Zootaxa, 2073, 57-68.

Van Soest, R.W.M., Boury-Esnault, N., Hooper, J.N.A., Rützler, K., de Voogd, N.J., Alvarez de Glasby, B., Hajdu, E., Pisera, A.B., Manconi, R., Schoenberg, C., Klautau, M., Picton, B., Kelly, M., Vacelet, J., Dohrmann, M., Díaz, M.C., Cárdenas, P. \& Carballo, J.L. (2017) World Porifera database. Available from: http://www.marinespecies.org/porifera/ (accessed 23 March 2017)

SUPPLEMENTAL TABLE 1. Spicule measurements for additional, non-type specimens of Cladorhiza kensmithi sp. nov. from the Northeast Pacific. Number of spicules measured (n), average length (L) and width (W, where available) in $\mu \mathrm{m} \pm$ standard deviation are shown. 